\title{
Colocalization of somatostatin receptors and epidermal growth factor receptors in breast cancer cells Heather L Watt ${ }^{1}$ and Ujendra Kumar*2
}

\author{
Address: ${ }^{1}$ Fraser Laboratories For Diabetes Research, Department of Medicine, Royal Victoria Hospital, McGill University, Montreal, Quebec, H3A \\ 1A1, Canada and 2Faculty of Pharmaceutical Sciences, Division of Pharmacology and Toxicology, The University of British Columbia, Vancouver, \\ BC, Canada \\ Email: Heather L Watt - heather.watt@mail.mcgill.ca; Ujendra Kumar* - ujkumar@interchange.ubc.ca \\ * Corresponding author
}

Published: 06 March 2006

Cancer Cell International 2006, 6:5 doi:10.1186/1475-2867-6-5

This article is available from: http://www.cancerci.com/content/6/1/5

(C) 2006 Watt and Kumar; licensee BioMed Central Ltd.

This is an Open Access article distributed under the terms of the Creative Commons Attribution License (http://creativecommons.org/licenses/by/2.0), which permits unrestricted use, distribution, and reproduction in any medium, provided the original work is properly cited.
Received: 06 October 2005

Accepted: 06 March 2006

\begin{abstract}
Background: Somatostatin receptor (SSTR) expression is positively correlated with tumor size and inversely correlated with epidermal growth factor receptor (ErbB) levels and tumor differentiation. In the present study, we compared SSTRI-5 and ErbBI-4 mRNA and protein expression in two breast cancer cell lines: MCF-7 (ER+) and MDA-MB-23 I (ER $\alpha-)$.

Results: All five SSTRs and four ErbBs were variably expressed as both cell surface and cytoplasmic proteins. In both cell lines, SSTR4 and SSTR I were highly expressed, followed by SSTR2 and SSTR5 with SSTR3 being the least expressed subtype, at the protein level. ErbBs were variably expressed with ErbBI as the predominant subtype in both cell lines. ErbBI is followed by ErbB3, ErbB2 and ErbB4 in MCF-7 at both the protein and mRNA levels. In MDA-MB-23 I cells, ErbBI is followed by ErbB2, ErbB4 and ErbB3. Our results indicate significant correlations at the level of mRNA and protein expression in a cell and receptor-specific manner. Using indirect immunofluorescence, we found that, in MCF-7 cells, SSTR5 was the most prominent subtype coexpressed with ErbBs followed by SSTR3, SSTR4, SSTRI and SSTR2, respectively. In MDA-MB-23I cells, SSTRI colocalized strongly with ErbBs followed by SSTR5, SSTR4, SSTR3 and SSTR2. ErbBs displayed higher levels of colocalization amongst themselves in MCF-7 cells than in MDA-MB-23 I cells.
\end{abstract}

Conclusion: These findings may explain the poor response to endocrine therapy in ER-cancer. Differential distribution of SSTR subtypes with ErbBs in breast cancer cells in a receptor-specific manner may be considered as a novel diagnosis for breast tumors.

\section{Background}

Somatostatin (SST) is an endogenously produced peptide in neuroendocrine and immune cells. It exists as two biologically active forms, SST-14 and SST-28, which are produced by tissue-specific proteolytic processing of a common precursor [1]. SST is a potent inhibitor of hormone and growth factor secretion as well as a modulator of cell proliferation $[2,3]$. These actions are mediated by a family of G protein-coupled receptors (GPCR) with five known subtypes (SSTR1-5). SST exerts antiproliferative effects on normal dividing cells, such as intestinal mucosal cells, activated lymphocytes and inflammatory cells as well as on solid tumors and cultured cells derived from both endocrine and epithelial tumors. These effects include cytostatic (growth arrest) and cytotoxic (apoptotic) actions and are mediated (i) directly by SSTRs 


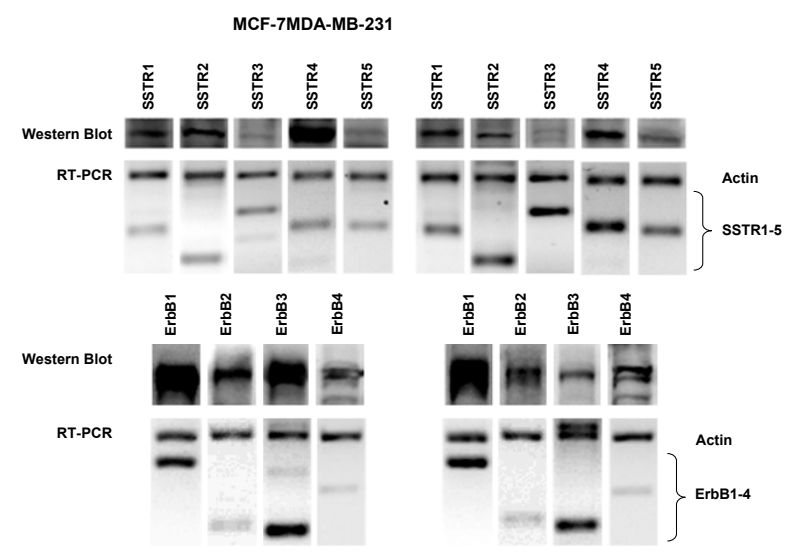

\section{Figure I}

Semi-quantitative analysis of SSTRI-5 and ErbBI-4 mRNA and protein expression in MCF-7 and MDA-MB-23I breast cancer cells. A. Upper panel shows western blot analysis of SSTRI-5 in MCF-7 (left) and MDA-MB-23I (right) cells. Membrane protein $(25 \mu \mathrm{g})$ was fractionated by SDS-PAGE and probed with affinity-purified SSTR antibodies. Major protein bands of 53 (SSTRI), 57 (SSTR2), 60 (SSTR3), 44 (SSTR4) and $58 \mathrm{kDa}$ (SSTR5) were obtained. Lower panel shows RT-PCR anlaysis of SSTRI-5 mRNA expression in both cell lines. $5 \mu \mathrm{g}$ of DNA-free RNA was reverse transcribed and coamplified with primers specific for SSTR I-5 and $\beta$-actin. $8 \mu \mathrm{L}$ of PCR products were fractionated on agarose gels stained with ethidium bromide, visualized under UV lighting and photographed. B. Western blot (upper panel) and RT-PCR (lower panel) analysis of ErbBI-4 expression in MCF-7 (left) and MDA-MB-23 I (right) breast tumor cells. Major protein bands of I70 (ErbBI), I 85 (ErbB2), 200

(ErbB3) and $175 \mathrm{kDa}$ (ErbB4) were obtained. Experimental conditions were the same as described for panel A except for the specific antibodies and primers.

present on tumor cells, and (ii) indirectly via SSTRs present on non-tumor cell targets. SST inhibits the secretion of hormones and growth factors that promote tumor growth, inhibits growth factor-induced DNA synthesis, inhibits angiogenesis, promotes vasoconstriction and modulates immune cell function [1]. Moreover, immunoreactive SST has been identified, by immunohistochemistry, in $30 \%$ of breast cancer samples and in several breast cancer cell lines $[4,5]$. Whether SST is synthesized and secreted from these cells and acts as a paracrine/autocrine growth inhibitor remains to be established.

All five SSTRs have been implicated in antiproliferative signaling in a subtype selective manner. When studied as individual isotypes, four of the receptors (SSTR1, 2, 4, 5) induce cell cycle arrest whereas SSTR3 uniquely triggers apoptosis $[3,6]$. Previous studies have demonstrated the presence of SSTRs in a large variety of tumors and cancer cell lines [7-9]. In addition, 15-66\% of primary human breast tumors are SSTR-positive by binding analysis [1014]. Consistent with previous studies, we have recently shown that SSTRs are expressed in breast cancers in variable amounts and are correlated with various histological markers in a receptor-specific manner [15]. We have also shown the effects of estradiol and tamoxifen on SSTR1 and SSTR2 expression in breast cancer cells [16].

Epidermal growth factor receptors, members of the type I receptor tyrosine kinase (RTK) family commonly known as ErbBs, are also variably distributed in breast tumors and breast cancer cell lines as are SSTRs $[17,18]$. ErbBs can be detected in all tumors with variable degrees of expression. There are currently four known ErbB receptors with ErbB1 (also known as EGFR) and ErbB2 (also known as Neu or HER2) being the most likely to be overexpressed in cancers, and, therefore, the most studied [19-22]. ErbB3 and ErbB4 (also known as HER3 and HER4, respectively) have been investigated the least. ErbBs exist as monomers and, upon ligand activation or when overexpressed, form homo- and heterodimers $[23,24]$.

Previous studies showed that ErbB1 is expressed in 40$50 \%$ of breast cancer cases and is inversely related with estrogen receptor (ER) levels and survival [25-27]. This is associated with more aggressive proliferation and unresponsiveness to hormone treatment $[12,14,27]$. Similarly, ErbB2 is present in $10-40 \%$ of breast cancer cases and is associated with poor survival $[19,21,25,26]$. ErbB3 is also expressed in breast cancer $[28,29]$. Associations with ErbB1 and ER have been shown in some studies but not in others [20]. This discrepancy may be due to the techniques employed, antibodies used, sample size or tumor type. In contrast with ErbB1-3, ErbB4 is generally reported to be associated with favorable prognostic factors $[20,21,25,30,31]$.

While ErbBs are involved in tumor growth and cell proliferation and are often associated with poor response to endocrine therapy and reduced survival, SSTRs play a major role in the control of tumor growth and tumor cell proliferation [32-34]. SSTR expression is positively correlated with tumor size and inversely correlated with ErbB levels and tumor differentiation $[12,14]$. Several recent reports have shown GPCRs to directly interact with RTKs via scaffolding proteins when both receptors are present together in the large signaling complexes [35-37]. Alternatively, GPCRs can indirectly transactivate RTKs via G proteins which ultimately lead to increased intracellular calcium levels and activation of PKC [38]. Indirect RTK transactivation has also been reported to occur via membrane-bound metalloproteinases (MMPs) or metallopro- 
Table I: Semiquantitative analysis of relative protein expression levels of SSTR I-5 in MCF-7 and MDA-MB-23 I cells as determined by western blot analysis.

\begin{tabular}{lcc}
\hline & MCF-7 & MDA-MB-23I \\
\hline SSTRI & ++ & +++ \\
SSTR2 & +++ & ++ \\
SSTR3 & + & + \\
SSTR4 & ++++ & +++ \\
SSTR5 & + & +
\end{tabular}

++++ strong +++ moderate ++ mild + weak

teinase-disintegrin proteins (ADAMs) which process ErbB transmembrane ligands $[35,39,40]$. In general, RTK transactivation by GPCRs results in altered mitogen activated protein kinase (MAPK) signaling and, subsequently, in altered cell growth and proliferation $[39,41,42]$. It is not known if SSTRs (GPCR) and ErbBs (RTK) are coexpressed within the same cells. Hence, before defining the mechanisms for functional interactions between ErbBs and SSTRs, it is essential to determine if this occurs. We have therefore determined, in the current study, SSTR1-5 and ErbB1-4 expression at the protein and mRNA levels. In addition, since ER has been shown to be associated with ErbB levels, we investigated their colocalization in ERpositive (ER+) and negative (ER-) breast cancer cells. Our data showed that SSTRs and ErbBs are well expressed in both cell lines and, significantly, exhibited variable colocalization.

\section{Results}

\section{Expression of SSTRs mRNA and protein in MCF-7 and} MDA-MB-23I cells

Using semi-quantitative RT-PCR, we determined SSTR1-5 mRNA expression in MCF-7 (ER+) and MDA-MB-231 (ER $\alpha-)$ human breast cancer cells (Fig. 1A). We found significant differences in overall receptor expression levels between ER+ and ER $\alpha$ - cells. Although SSTR mRNA levels were greater in MDA-MB-231 than in MCF-7 cells, both cells lines showed similar patterns of expression. SSTR3 was highly expressed, followed by SSTR4, SSTR2 and SSTR5 while SSTR1 was the least expressed subtype, at the level of the mRNA.

We further determined SSTR1-5 protein expression using western blot and indirect immunofluorescence analyses. Consistent with mRNA results and as detected by western blot, all SSTR subtypes were expressed at their representative molecular sizes at the protein level $(53,57,60,44$ and $58 \mathrm{kDa}$ for SSTR1-5, respectively) (Table 1 and Fig. 1A). Indirect immunofluorescence analysis of SSTR subtypes revealed a significant but variable cellular expression of multiple SSTRs with all five receptor subtypes expressed as both membrane and cytoplasmic proteins (Figs. 2, 3, 4, 5 , $6,7,8,9)$. Notably, SSTR1 and 4 were more highly expressed in MCF-7 cells than in MDA-MB-231 cells while SSTR3 was poorly expressed in both cell lines.

\section{Expression of ErbBs $m R N A$ and protein in MCF-7 and MDA-MB-23I cells}

All ErbB subtypes are well expressed at the mRNA level in a significant proportion of breast tumor tissues; however, expression in breast cancer cells is variable $[22,43,44]$. MCF-7 cells expressed all four ErbBs at the level of the mRNA with ErbB1 and ErbB3 being the dominant subtypes (Fig. 1B). MDA-MB-231 cells expressed all four ErbBs in a comparable manner, also displaying higher expression at the mRNA level for ErbB1 and ErbB3. Interestingly, in MCF-7 cells, ErbB3 mRNA expression was the strongest while, in MDA-MB-231 cells, ErbB1 mRNA was the most abundant. These results are in agreement with a report by Bièche et al. [43] where MCF-7 cells displayed lower ErbB1 mRNA levels, higher ErbB2 and ErbB3 levels and equivalent ErbB4 mRNA expression in comparison to MDA-MB-231 cells.

Using western blot analysis, ErbB subtypes in MCF-7 and MDA-MB-231 cells displayed variable expression at the protein level whereby all ErbBs were expressed at their representative molecular sizes $(170,185,200$ and 175 $\mathrm{kDa}$ for ErbB1-4, respectively). ErbB1 and ErbB3 were the predominant subtypes followed by ErbB2 and ErbB4 in MCF-7 cells as determined by western blot analysis (Table 2 and Fig. 1B). In contrast, in MDA-MB-231 cells, ErbB1 was predominantly expressed followed by ErbB2, ErbB4 and ErbB3. Consistent with previous reports, ErbB3 protein expression was strongest in ER+ cells while ErbB1 was more abundant in ER-cells [22]. However, our results contradict another report with regards to relative ErbB3 expression levels [28]. Protein expression was further confirmed by immunocytochemistry revealing that all ErbB subtypes were well expressed as membrane and cytoplasmic proteins in MCF-7 and MDA-MB-231 cells (Figs. 2, 3, $4,5,6,7,8,9,10,11)$.

\section{Colocalization of SSTRs and ErbBs in MCF-7 cells}

Colocalization between SSTRs and ErbBs revealed significant variations in a receptor and cell-specific manner. Four different cell populations were detected in MCF-7 

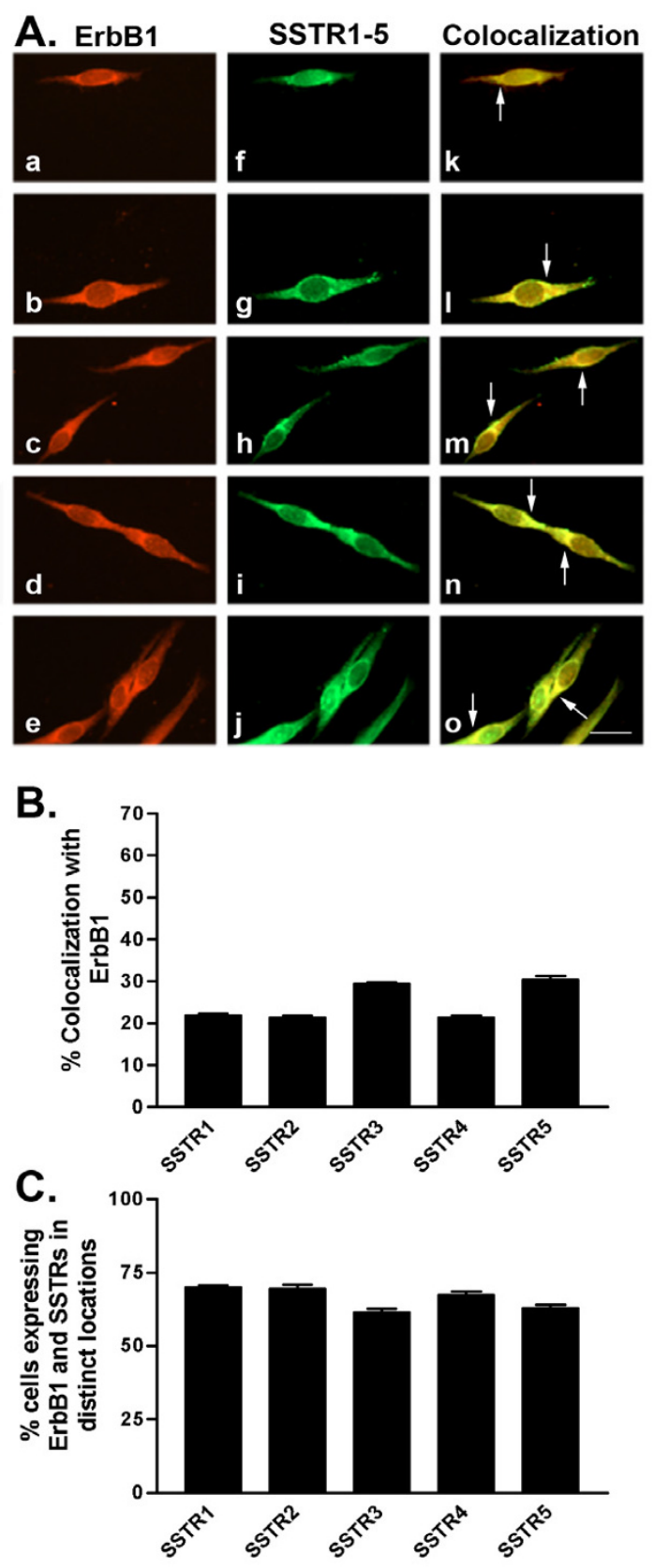

\section{Figure 2}

A. Representative photomicrographs illustrating double immunofluorescence localization of ErbBI and SSTRI-5 in MCF-7 cells. Localization of ErbBI (red staining) was visualized using monoclonal antibodies with Cy3-conjugated goat anti-mouse IgG (a-e). The same cells were incubated with polyclonal SSTRI-5 antibodies and visualized (green staining) using FITC-conjugated goat anti-rabbit IgG ( $\mathrm{f}-\mathrm{j})$. Colocalization of ErbBI and SSTRI-5 was determined by merging individual red and green images to give orange-labelled cells $(\mathrm{k}-\mathrm{o})$. All receptors are expressed as membrane and cytoplasmic protein. Arrows indicate colocalization at the cell surface. Scale bar $=25 \mu \mathrm{m}$. B. Quantitative analysis of MCF-7 cells showing colocalization of ErbBI with SSTRI-5. Cells expressing two receptors together were counted from at least 8 randomly selected vertical and horizontal fields from each coverslip. Data are from three different experiments performed in duplicate and are presented as mean \pm SEM for each receptor combination. C. Quantitative analysis of cells showing ErbBI and SSTRI-5 in distinct locations within the same cell. Data were analyzed as described in B. 

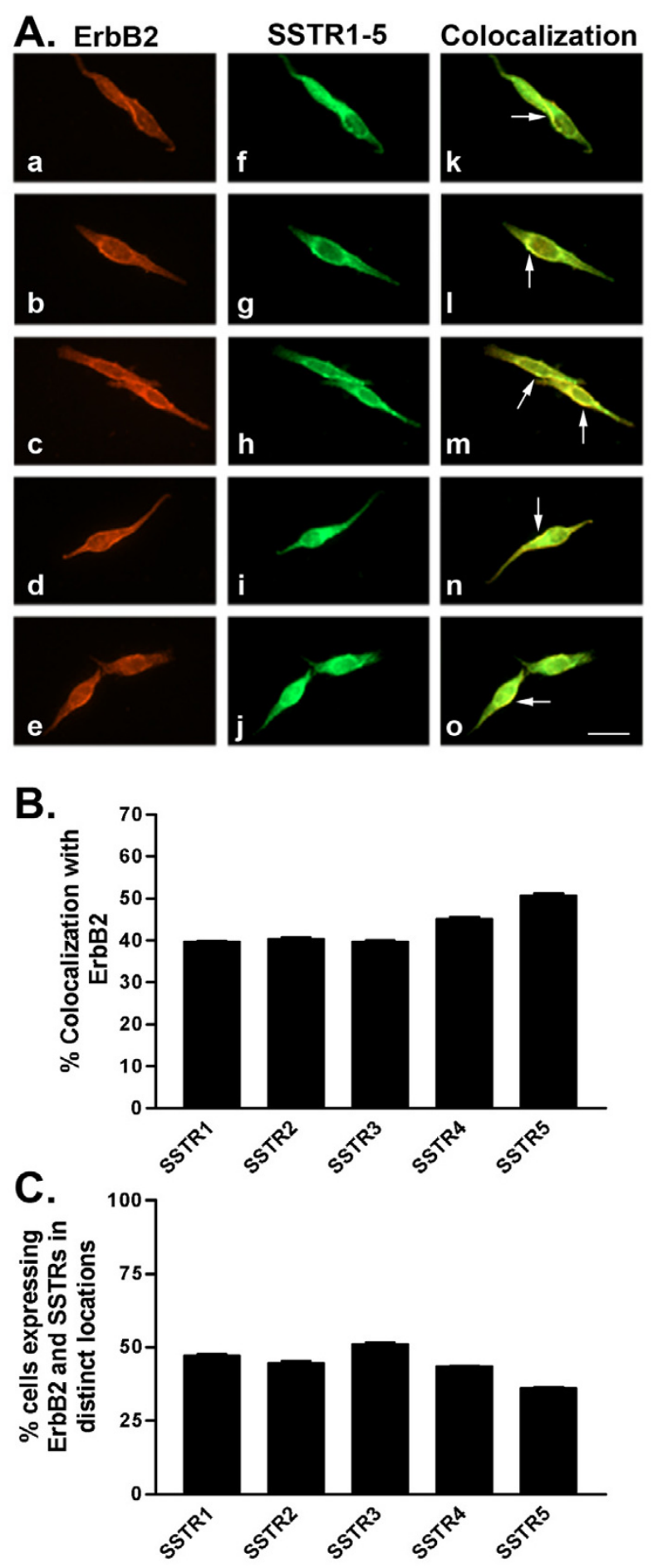

Figure 3

A. Representative photomicrographs illustrating double immunofluorescence localization of ErbB2 (red staining) and SSTR I-5 (green staining) in MCF-7 cells (for details see legend to Figure 2). Scale bar $=25 \mu \mathrm{m}$. B. Quantitative analysis of MCF-7 cells showing colocalization of ErbB2 with SSTRI-5 (for details see legend to Figure 2). C. Quantitative analysis of cells showing ErbB2 and SSTRI-5 in distinct locations within the same cell. Data were analyzed as described in Figure 2. 

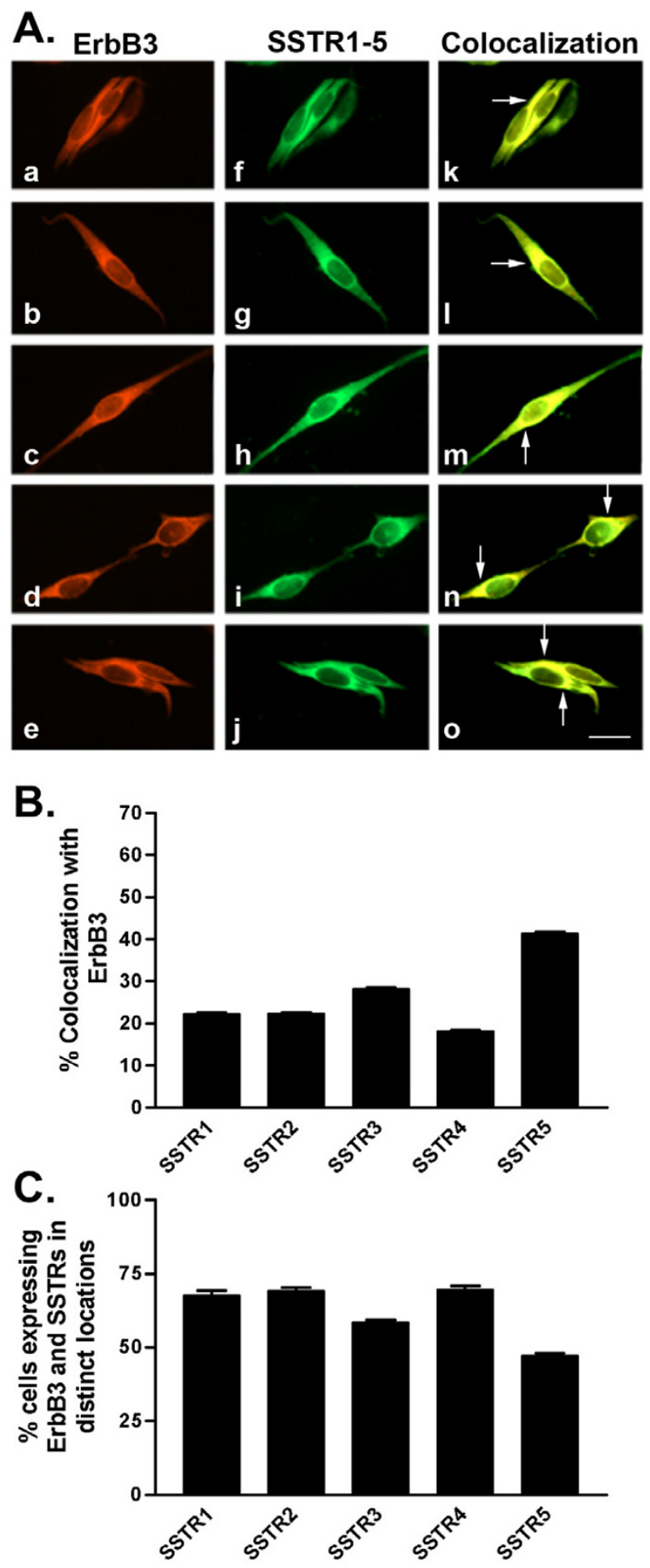

\section{Figure 4}

A. Representative photomicrographs illustrating double immunofluorescence localization of ErbB3 (red staining) and SSTRI-5 (green staining) in MCF-7 cells (for details see legend to Figure 2). Scale bar $=25 \mu \mathrm{m}$. B. Quantitative analysis of MCF-7 cells showing colocalization of ErbB3 with SSTRI-5 (for details see legend to Figure 2). C. Quantitative analysis of cells showing ErbB3 and SSTRI-5 in distinct locations within the same cell. Data were analyzed as described in Figure 2. 

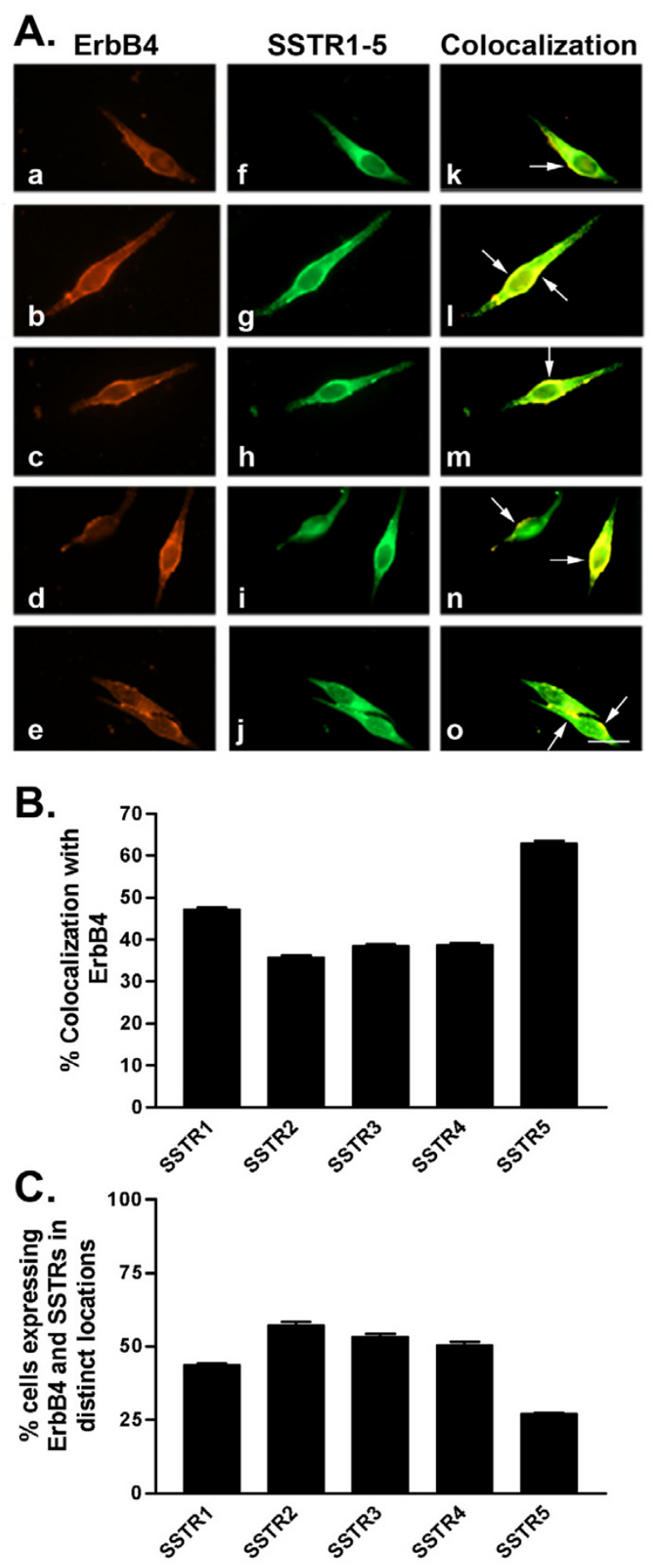

\section{Figure 5}

A. Representative photomicrographs illustrating double immunofluorescence localization of ErbB4 (red staining) and SSTR I-5 (green staining) in MCF-7 cells (for details see legend to Figure 2). Scale bar $=25 \mu \mathrm{m}$. B. Quantitative analysis of MCF-7 cells showing colocalization of ErbB4 with SSTRI-5 (for details see legend to Figure 2). C. Quantitative analysis of cells showing ErbB4 and SSTRI-5 in distinct locations within the same cell. Data were analyzed as described in Figure 2. 

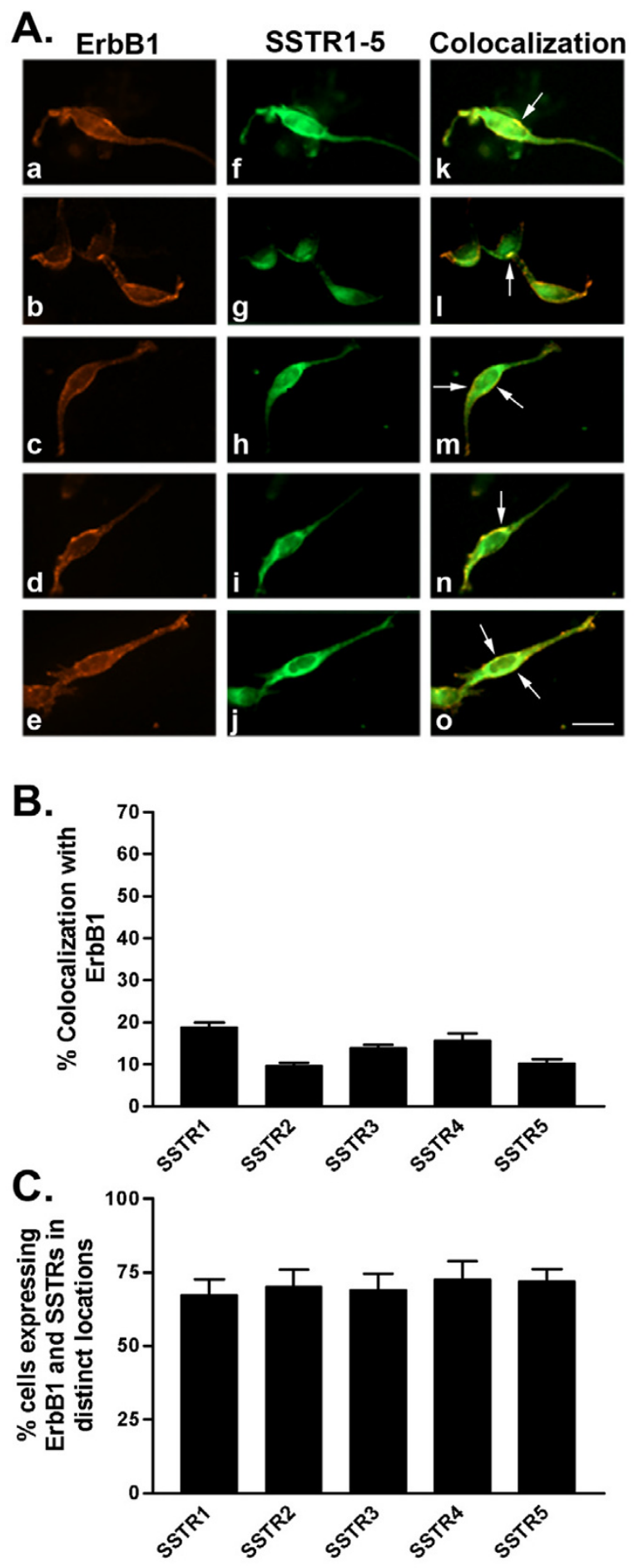

\section{Figure 6}

A. Representative photomicrographs illustrating double immunofluorescence localization of ErbBI (red staining) and SSTRI-5 (green staining) in MDA-MB-23I cells (for details see legend to Figure 2). Scale bar $=25 \mu \mathrm{m}$. B. Quantitative analysis of MDAMB-23 I cells showing colocalization of ErbBI with SSTRI-5 (for details see legend to Figure 2). C. Quantitative analysis of cells showing ErbBI and SSTRI-5 in distinct locations within the same cell. Data were analyzed as described in Figure 2. 

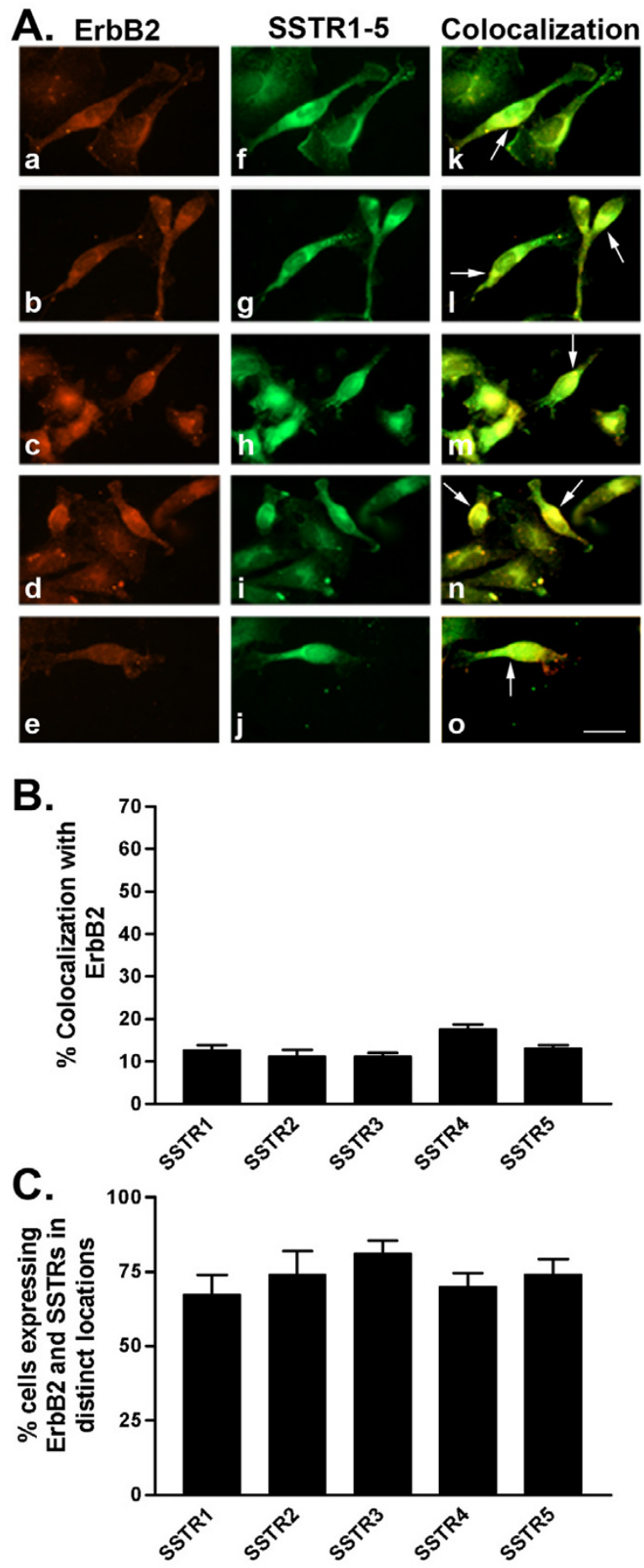

\section{Figure 7}

A. Representative photomicrographs illustrating double immunofluorescence localization of ErbB2 (red staining) and SSTRI-5 (green staining) in MDA-MB-23I cells (for details see legend to Figure 2). Scale bar $=25 \mu \mathrm{m}$. B. Quantitative analysis of MDAMB-23 I cells showing colocalization of ErbB2 with SSTRI-5 (for details see legend to Figure 2). C. Quantitative analysis of cells showing ErbB2 and SSTRI-5 in distinct locations within the same cell. Data were analyzed as described in Figure 2. 


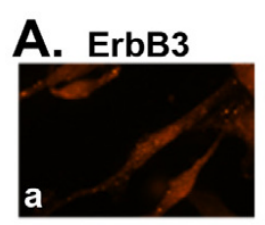

\section{SSTR1-5 Colocalization}
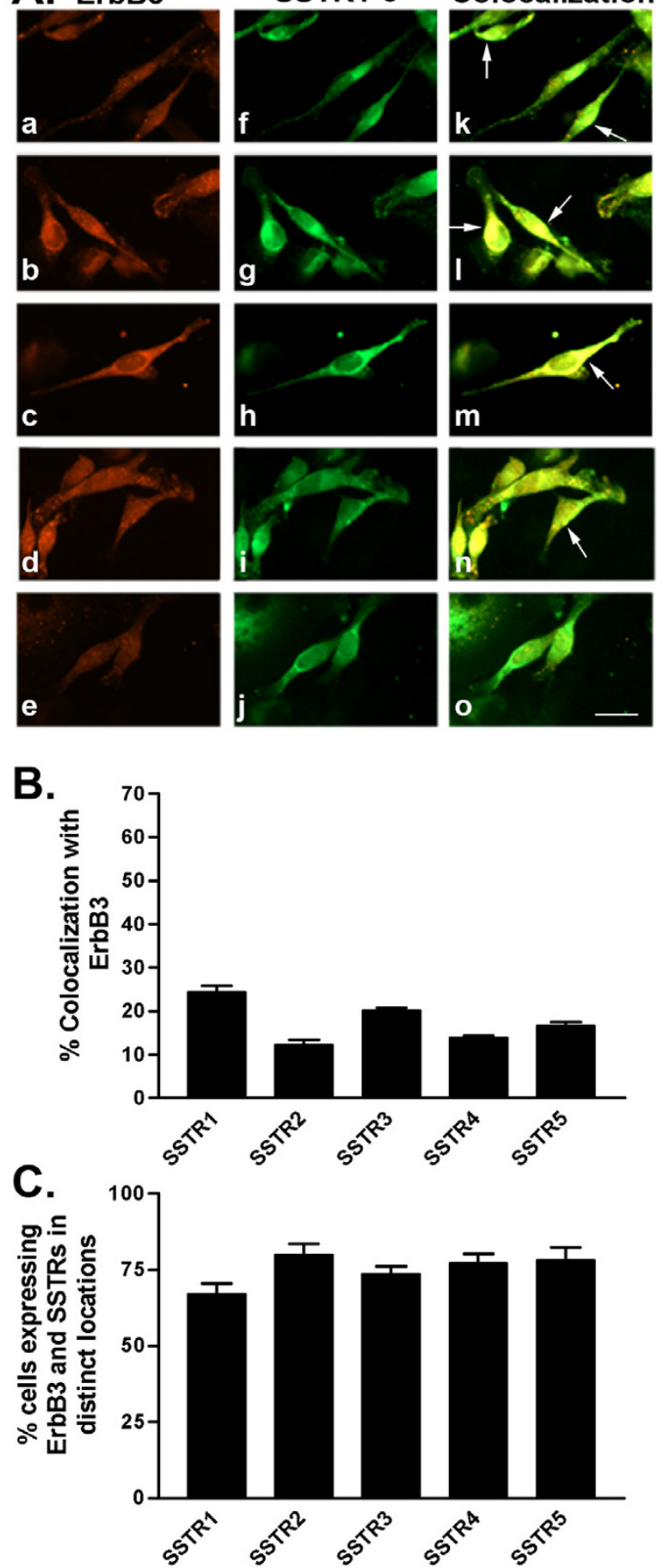

\section{Figure 8}

A. Representative photomicrographs illustrating double immunofluorescence localization of ErbB3 (red staining) and SSTRI-5 (green staining) in MDA-MB-23I cells (for details see legend to Figure 2). Scale bar $=25 \mu \mathrm{m}$. B. Quantitative analysis of MDAMB-23 I cells showing colocalization of ErbB3 with SSTRI-5 (for details see legend to Figure 2). C. Quantitative analysis of cells showing ErbB3 and SSTRI-5 in distinct locations within the same cell. Data were analyzed as described in Figure 2. 

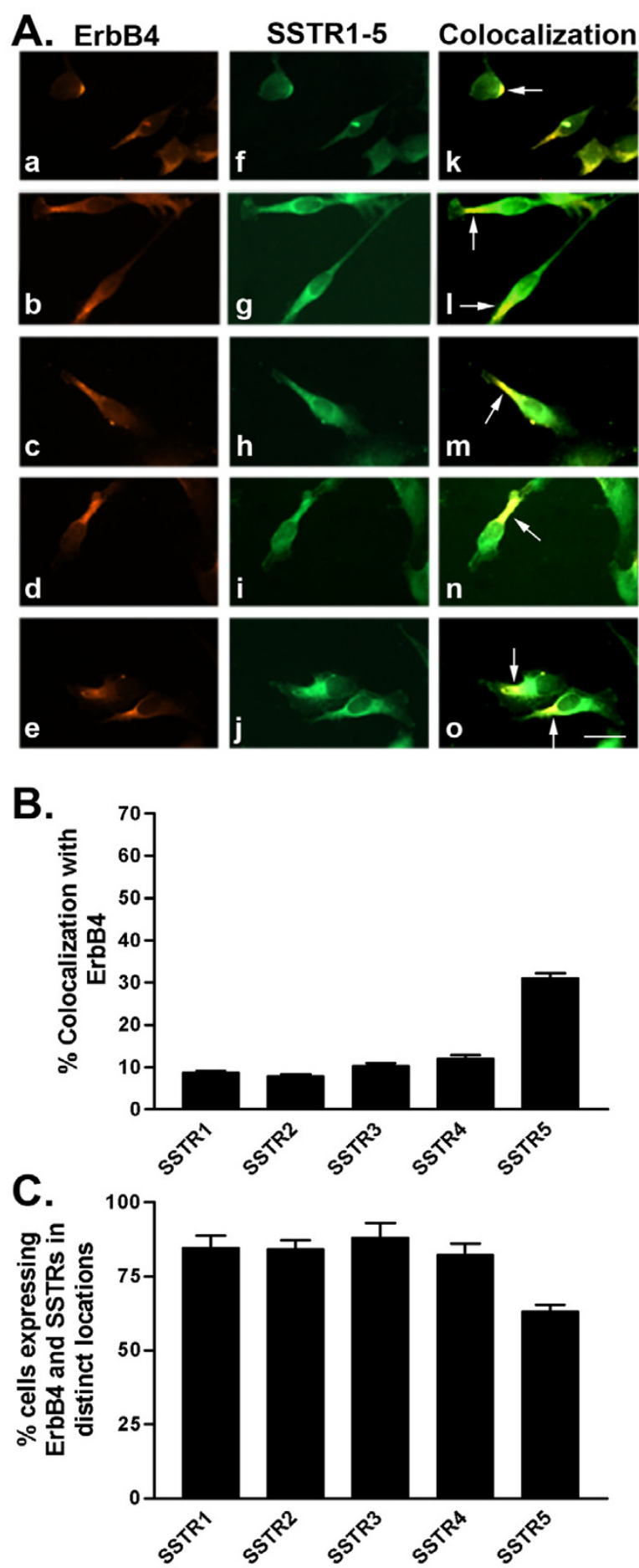

\section{Figure 9}

A. Representative photomicrographs illustrating double immunofluorescence localization of ErbB4 (red staining) and SSTR I-5 (green staining) in MDA-MB-23I cells (for details see legend to Figure 2). Scale bar $=25 \mu \mathrm{m}$. B. Quantitative analysis of MDAMB-23 I cells showing colocalization of ErbB4 with SSTRI-5 (for details see legend to Figure 2). C. Quantitative analysis of cells showing ErbB4 and SSTRI-5 in distinct locations within the same cell. Data were analyzed as described in Figure 2. 
Table 2: Semiquantitative analysis of relative protein expression levels of ErbB I-4 in MCF-7 and MDA-MB-23 I cells as determined by western blot analysis.

\begin{tabular}{|c|c|c|}
\hline & MCF-7 & MDA-MB-23I \\
\hline ErbB I & ++++ & ++++ \\
\hline ErbB2 & ++ & +++ \\
\hline ErbB3 & +++ & + \\
\hline ErbB4 & ++ & ++ \\
\hline
\end{tabular}

++++ strong +++ moderate ++ mild + weak

cells: one expressing SSTRs alone $(\leq 7 \%)$, a second population expressing only ErbBs $(\leq 15 \%)$, a third population expressing both receptors in distinct locations within the same cell (27-70\%) and a fourth population of cells displaying colocalization (18-62\%).

In MCF-7 cells, SSTR1 colocalized with ErbB1 (22\% of cells) at the cell membrane and intracellularly (Table 3 and Fig. 2). SSTR2 and SSTR4 exhibited similar patterns of colocalization with ErbB1 with only $21 \%$ of cells coexpressing both receptors. SSTR3 and SSTR5 colocalized with ErbB1 in a greater proportion (30\%) of cells. All SSTR subtypes colocalized with ErbB2 in a comparable manner at the cell surface as well as intracellularly (Table 3 and Fig. 3). ErbB2 and SSTRs colocalized in $40-51 \%$ of cells with SSTR5 displaying the strongest colocalization with ErbB2. ErbB3 was coexpressed with SSTR1-5 in a comparable manner to ErbB1 (Table 3 and Fig. 4). SSTR1 and SSTR2 colocalized with ErbB3 in 22\% of cells whereas SSTR3 and SSTR4 were coexpressed in 28 and 18\% of ErbB3-positive cells, respectively. In contrast, SSTR5 colocalized with ErbB3 in about $41 \%$ of cells. In MCF-7 cells, ErbB4 colocalized with all SSTR subtypes (Table 3 and Fig. 5). ErbB4 was coexpressed with SSTR2, SSTR3, and SSTR4 in a comparable manner (36-39\% of cells). On the other hand, SSTR1 and SSTR5 colocalized with ErbB4 in 47 and $63 \%$ of cells, respectively. Further colocalization studies revealed that SSTR5 was the most prominent SSTR subtype to colocalize with ErbB1-4 in MCF-7 cells (Table 3 and Figs. 2, 3, 4, 5).

\section{Colocalization of SSTRs and ErbBs in MDA-MB-23I cells} In comparison with MCF-7 (ER+) cells, MDA-MB-231 (ER $\alpha-)$ cells exhibited significantly variable colocalization of SSTR1-5 with ErbB1-4. Furthermore, a lower percentage of cells coexpressed both SSTRs and ErbBs in MDA-MB231 than in MCF-7 cells. Interestingly, using immunocytochemistry, $100 \%$ of MDA-MB-231 cells expressed ErbB1-3. Subsequently, there were no cells that only expressed SSTRs when the cells were double-labeled for SSTRs and ErbB1-3. In contrast, up to 3\% of cells showed staining for SSTRs alone while up to $20 \%$ of cells only expressed ErbB4 in cells double-labeled for SSTR1-5 and ErbB4. Furthermore, there was a small cell population $(\leq$ $1 \%$ ) lacking both receptors.

As illustrated in Table 3 and Figure 6, 19\% of MDA-MB231 cells displayed strong colocalization between SSTR1 and ErbB1. On the other hand, SSTR2-5 colocalization with ErbB1 occurred in only $10-16 \%$ of cells (Table 3 and Fig. 6). In MDA-MB-231 cells, ErbB2 weakly colocalized with all SSTR subtypes at the cell surface in only $11-18 \%$ of cells (Table 3 and Fig. 7). SSTR1 was coexpressed with ErbB3 in 24\% of cells (Table 3 and Fig. 8). SSTR2, SSTR3 and SSTR4 colocalized with ErbB3 at the cell surface and intracellularly in approximately 12, 20 and 14\%, respectively, of the cell population (Table 3 and Fig. 8). Meanwhile, SSTR 5 displayed colocalization (17\% of cells) with ErbB3 mainly at the cell surface. In MDA-MB-231 cells, SSTR1-4 colocalized with ErbB4 at the cell surface in 812\% of cells (Table 3 and Fig. 9). In contrast, SSTR5 and ErbB4 colocalization was seen in $31 \%$ of cells. Notably, colocalization of SSTRs with ErbB4 occurred mainly in the "apical" endings of the cells.

\section{Colocalization of ErbBs in MCF-7 cells and MDA-MB-23 I cells}

To better understand whether there is any preferential and selective colocalization between ErbB subtypes in ER+ and ER-cells, we determined the colocalization of ErbBs in

Table 3: Colocalization of SSTR I-5 with ErbB I-4 in MCF-7 and MDA-MB-23 I cells.

\begin{tabular}{|c|c|c|c|c|c|c|c|c|}
\hline & \multicolumn{4}{|c|}{ MCF-7 } & \multicolumn{4}{|c|}{ MDA-MB-23 I } \\
\hline & ErbB I & ErbB2 & ErbB3 & ErbB4 & ErbB I & ErbB2 & ErbB3 & ErbB4 \\
\hline SSTR I & + & ++ & + & +++ & ++ & + & +++ & + \\
\hline SSTR2 & + & ++ & + & ++ & + & + & + & + \\
\hline SSTR3 & +++ & ++ & ++ & ++ & ++ & + & ++ & + \\
\hline SSTR4 & + & +++ & + & ++ & ++ & ++ & + & + \\
\hline SSTR5 & +++ & +++ & +++ & ++++ & + & + & ++ & +++ \\
\hline
\end{tabular}



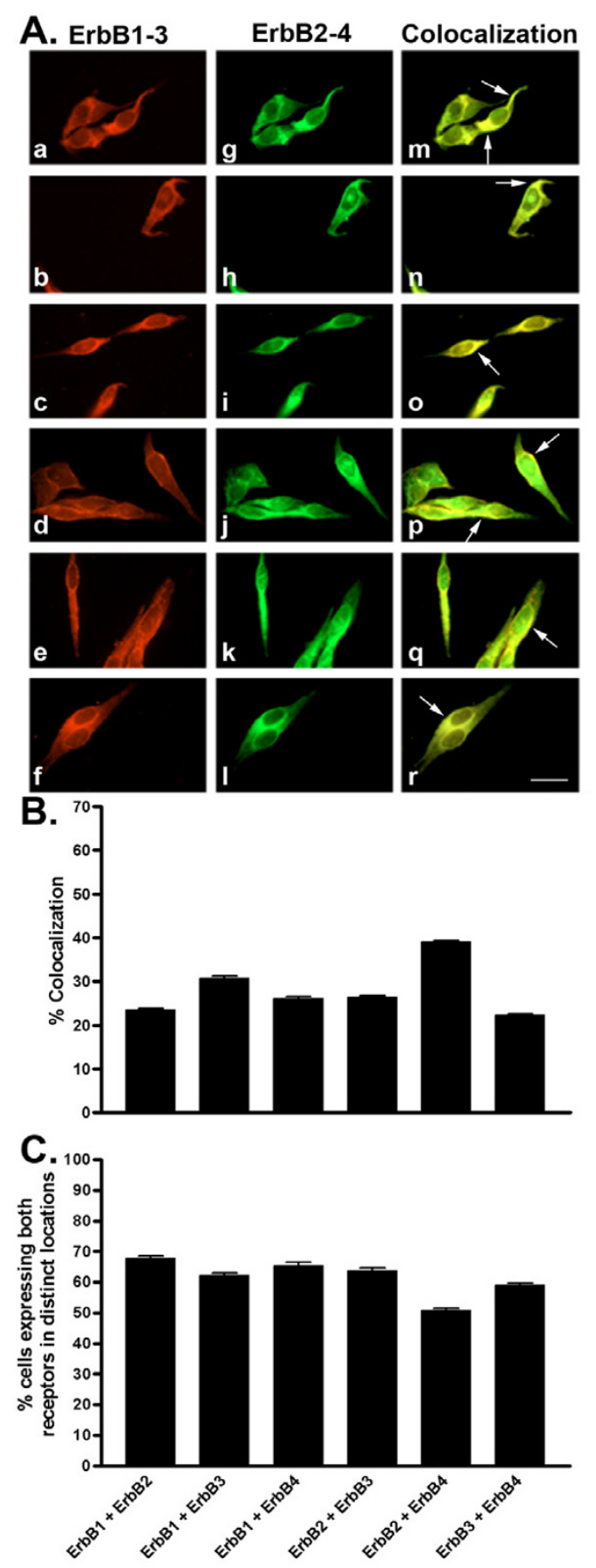

Figure 10

A. Representative photomicrographs illustrating double immunofluorescence localization of ErbBI-3 and ErbB2-4 in MCF-7 cells. Localization of ErbBI-3 (red staining) was visualized using monoclonal antibodies with Cy3-conjugated goat anti-mouse IgG (a-f). The same cells were incubated with polyclonal ErbB2-4 antibodies and visualized (green staining) using FITC-conjugated goat anti-rabbit $(\mathrm{g}-\mathrm{l})$. Colocalization of ErbBI-3 and ErbB2-4 was determined by merging individual red and green images to give orange-labelled cells $(\mathrm{m}-\mathrm{r})$. All receptors are expressed as membrane and cytoplasmic protein. Arrows indicate colocalization at the cell surface. Scale bar $=25 \mu \mathrm{m}$. B. Quantitative analysis of MCF-7 cells showing colocalization of ErbBI-3 with ErbB2-4 (for details see legend to Figure 2). C. Quantitative analysis of cells showing ErbBI-3 and ErbB2-4 in distinct locations within the same cell. Data were analyzed as described in Figure 2. 

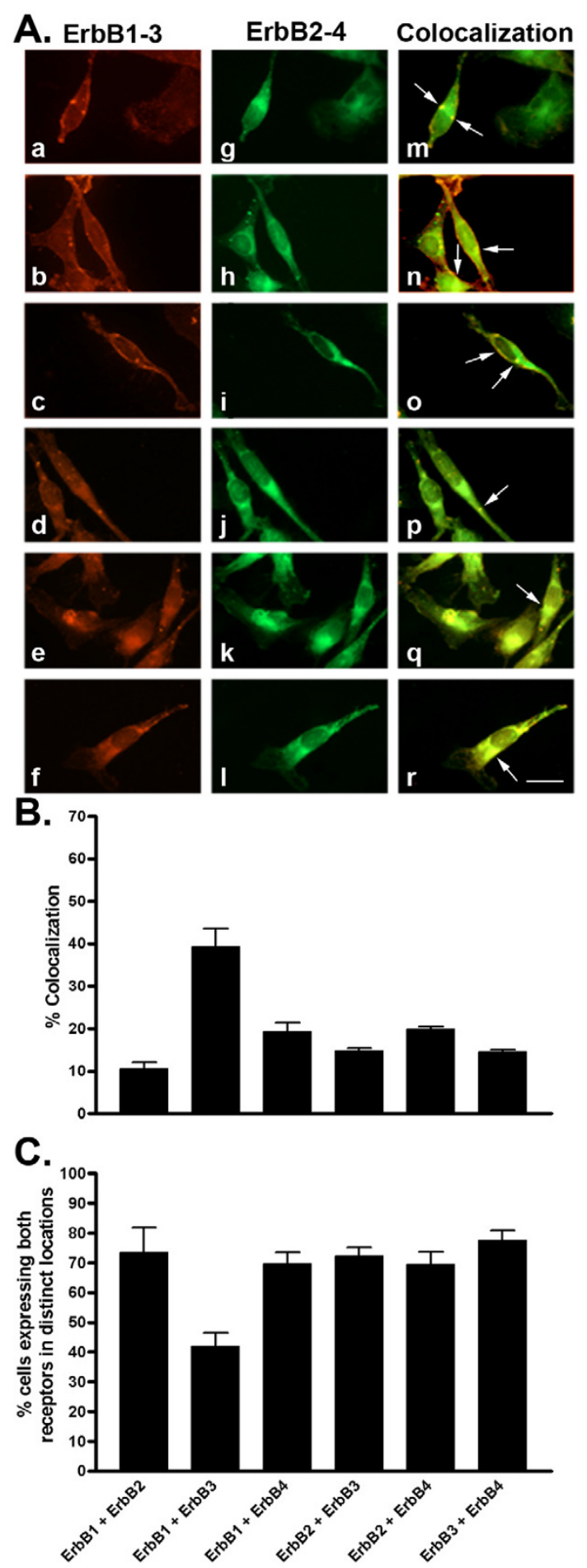

Figure I I

A. Representative photomicrographs illustrating double immunofluorescence localization of ErbBI-3 and ErbB2-4 in MDA-MB$23 \mathrm{I}$ cells (for details see legend to Figure 10). Scale bar $=25 \mu \mathrm{m}$. B. Quantitative analysis of MDA-MB-23 I cells showing colocalization of ErbBI-3 with ErbB2-4 (for details see legend to Figure 2). C. Quantitative analysis of cells showing ErbBI-3 and ErbB2-4 in distinct locations within the same cell. Data were analyzed as described in Figure 2. 
MCF-7 and MDA-MB-231 cells. As shown in MCF-7 cells (Fig. 10), ErbB2, ErbB3 and ErbB4 colocalized with ErbB1 in $23 \%, 31 \%$ and $26 \%$ of cells, respectively. Furthermore, ErbB3 and ErbB4 were coexpressed with ErbB2 in 26\% and 39\%, respectively, while ErbB3 and ErbB4 colocalized in $22 \%$ of MCF-7 cells. In contrast, MDA-MB-231 cells demonstrated lesser degrees of colocalization than MCF-7 cells with the exception of ErbB1 and ErbB3 (Fig. 11). ErbB1 colocalized with ErbB2, ErbB3 and ErbB4 in 11\%, $39 \%$ and $19 \%$ of cells, respectively. Meanwhile, ErbB3 and ErbB4 colocalized with ErbB2 in 15\% and 20\% of cells, respectively, and ErbB3 and ErbB4 were coexpressed in $14 \%$ of the cell population.

\section{Discussion}

The present study represents the first comprehensive description showing SSTR1-5 and ErbB1-4 colocalization in ER+ and ER-breast cancer cells. All five SSTRs were detected in MCF-7 and MDA-MB-231 with a rich expression of subtypes 1 and 4, moderate expression of SSTR2 and relatively weak expression of subtypes 3 and 5. Our data also demonstrate a potential correlation between SSTR and ErbB expression and estrogen dependency. We found higher levels of expression of ErbB1 and lower levels of SSTR1, SSTR4 and ErbB3 in ER $\alpha$ - (MDA-MB-231) cells when compared to ER+ (MCF-7) breast cancer cells. In addition, we showed that there was more colocalization of SSTRs with ErbBs in MCF-7 cells than in MDA-MB231 cells. We also detected preferential colocalization among ErbBs in both MCF-7 and MDA-MB-231 cells.

Overall expression levels of SSTR subtypes in cultured breast cancer cell lines were comparatively less than in solid tumors. Significantly, SSTR3, which is well expressed in breast tumor tissues, was relatively poorly expressed in these cell lines [15]. These results indicate that the various breast cancer cell lines, although useful for studying SSTR biology, do not necessarily reflect endogenous tumor SSTR expression or function. Possible explanations for the difference are the probable induction of SSTR expression in solid tumors by circulating hormones, or, locally, by growth factors, cytokines, and other mediators produced from peritumoral structures such as the stroma, blood vessels and immune cells [45]. Increasing evidence points to the occurrence of multiple SSTR subtypes in many different types of tumor cells as well as normal cells [46,47]. All five SSTR isoforms bind the natural ligands SST-14 and SST-28 with nanomolar affinity and share common signaling pathways, such as the inhibition of adenylyl cyclase, making the functional significance of expressing more than one SSTR subtype in the same cell unclear [2]. Whether the different SSTRs subserve different biological roles in the same cell or cooperate through dimerization to create greater signaling diversity remains to be determined. In this regard, we have recently shown that SSTR1 and SSTR5 heterodimerization, in stably transfected HEK and CHO-K1 cells, results in a new receptor with enhanced signaling properties $[48,49]$. We further anticipate such a possibility of heterodimerization between SSTR1 and SSTR5 and, additionally, between SSTRs and ErbBs in breast cancer cells.

Whereas SSTRs have been associated with antiproliferative signaling, several previous studies, using a variety of tumors including MCF-7 and MDA-MB-231 cells, have correlated ErbBs with tumor progression and poor prognosis $[19,22,50,51]$. However, the data have been inconsistent and controversial [52-54]. These inconsistencies may have arisen due to the techniques employed, the variation between cell stocks studied in different laboratories and, most significantly, the different passages at which the cells were used [45]. In this regard, we have seen significant variation in receptor expression/levels at different passages (data not shown). In keeping with ErbBs roles in tumor progression and poor prognosis, overexpression of ErbBs in breast carcinomas has been correlated with a lack of ER [44,52]. Furthermore, blocking ER using antisense strategies resulted in increased ErbB1, no change in ErbB2 and a slight decrease in ErbB3 expression in breast cancer cells [22]. Consistent with these observations, we found higher levels of expression of ErbB1 and decreased levels of ErbB3 in ER $\alpha$ - (MDA-MB-231) than in ER+ (MCF-7) cells. In accordance with previous studies, our findings strongly support the concept that the presence of ER could be a determining factor in ErbB expression in both breast cancer cells and tumors.

Previous reports state that specific ErbB heterodimers, i.e., ErbB1/ErbB2 and ErbB2/ErbB3, result in increased tumor growth and cell proliferation. We report that, in MCF-7 and MDA-MB-231 cells, there is preferential colocalization of ErbBs with other ErbBs. We found greater colocalization between ErbB1 and ErbB3 in both MCF-7 and MDA-MB-231 cells. We also detected a high degree of colocalization between ErbB2 and ErbB4 in MCF-7 cells. These data strongly support previous observations whereby heterodimerization between ErbB1 and ErbB2 was correlated with tumor progression [22,51]. These alternate heterodimer pairs, i.e., ErbB1/ErbB3 and ErbB2/ ErbB4, may account for the less aggressive proliferation rates reported for both cell lines. Furthermore, in agreement with previous studies, we detected fewer cells showing ErbB colocalization in ER $\alpha$ - cells (MDA-MB-231) than in ER+ (MCF-7) cells with the exception of those coexpressing ErbB1 and ErbB3. Altogether, the higher degree of colocalization of ErbBs in MCF-7 cells than in MDA-MB-231 cells may be partially associated with slower tumor growth and better response to hormonal therapy. Our data provide direct evidence that ErbB1 and ErbB3 are the prominent subtypes which may interact as 
heterodimers, in these cells. Nothing is currently known regarding the physiological responses and functional consequences of these observations suggesting that further studies are required in this direction.

In addition to heterodimerization within receptor subfamilies, there have been several reports demonstrating that crosstalk between RTKs and GPCRs modulates downstream signaling pathways [35-37]. Even so, direct evidence for functional interactions between ErbBs and SSTRs have not yet been demonstrated despite the critical roles they play in tumor progression. We showed here that there was increased colocalization of SSTRs with ErbBs in MCF-7 cells (ER+) compared with MDA-MB-231 (ER $\alpha-)$ cells. This may help elucidate why estrogen-sensitive tumors show less aggressive proliferation than estrogeninsensitive tumors. This pattern of colocalization may also explain the superior response of ER+ patients to SST analog therapy [55]. In MCF-7 cells, the preferentially greater colocalization of SSTRs with ErbB2 may serve to counteract any deleterious effects of ErbB2. Whether this colocalization exists in vivo and is lost during tumor progression needs to be determined. Furthermore, colocalization of SSTR1 and SSTR5 with ErbB4 supports the antiproliferative effects of both SSTRs. SSTR interactions with ErbB4 may also serve to potentiate ErbB4's previously reported role in differentiation and apoptosis [30]. Furthermore, by preventing ErbB4's downregulation, SSTRs may be indirectly circumventing ErbB1-3's growth promoting effects. However, whether such interactions exist in vivo in solid tumors needs to be determined.

Despite SSTR and ErbB colocalization, low abundance of SSTRs alongside high expression of ErbBs within the same cell may account for the failure of SST treatment of breast tumor or other ErbB-expressing tumors. Furthermore, it is anticipated but not yet proven that SSTRs would reverse the effects of ErbBs with respect to MAPK activation and subsequent cell proliferation [56-58]. In addition, some reports suggest that the ER is involved in MAPK activation [59-61]. Previous studies have also demonstrated that ER presence is required for cbl-induced ubiquitination of ErbB1 and that ubiquitination of ErbB1 results in its degradation [62]. This could result in different levels of activation of downstream pathways in ER+ (MCF-7) and ER $\alpha$ - (MDA-MB-231) breast cancer cells. In addition, SSTinduced internalization and subsequent downregulation of SSTR2-5 on the membrane may release ErbBs from complexes and result in cell proliferation [63-65]. Altogether, this suggests that not only do we need to activate SSTRs to counteract ErbBs effects on cell proliferation but we also need a mechanism to upregulate, or at least maintain, SSTRs on the membrane in order to reduce or modify ErbB signaling.

\section{Conclusion}

In summary, the present results have important functional and therapeutic implications. Predominant SSTR1 expression and weak SSTR5 expression in breast cancer cells may help explain their poor sensitivity to hormonal therapy. These data may also explain the differential effects of the SST analog octreotide in breast cancer therapy. Since there is evidence of crosstalk between GPCRs and RTKs, cells displaying SSTR colocalization with ErbB suggest that, within these cells, both receptor families may functionally interact through hetero-oligomerization. If such a process exists, it may account for the diversification of receptor signaling. Most significantly, developing a new therapeutic agent that could both activate SSTRs and inhibit ErbB overexpression could potentially be a way to block tumor progression.

\section{Materials and methods Materials and reagents}

RPMI 1640 and L-15 culture media were purchased from Invitrogen (Burlington, Ontario). Fetal bovine serum (FBS) and Antibiotic-Antimycotic solution were purchased from Wisent (St. Bruno, Quebec). The protease inhibitor cocktail used for protein extraction was supplied by Sigma-Aldrich Canada Ltd (Oakville, Ontario). Normal goat serum (NGS) was purchased from Vector Laboratories (Burlington, Ontario). Polyclonal rabbit antiSSTR antibodies were developed in the lab and their specificity has been previously described $[66,67]$. Purified mouse anti-ErbB1 (sc-101), ErbB2 (sc-08), ErbB3 (sc7390), rabbit anti-ErbB1 (sc-03), ErbB2 (sc-284), ErbB3 (sc-285), ErbB4 (sc-283) and goat anti-ErbB4 (sc-283-G) were purchased from Santa Cruz Biotechnology (Santa Cruz, California). The secondary FITC- and Cy3-conjugated goat anti-mouse or anti-rabbit and Cy3-conjugated donkey anti-sheep IgG antibodies were obtained from Jackson ImmunoResearch Laboratories (West Grove, Pensylvania).

\section{Cell culture}

MCF-7 cells were maintained in RPMI 1640 medium supplemented with $0.35 \mu \mathrm{M}$ insulin, $10 \%(\mathrm{v} / \mathrm{v})$ FBS and $1 \%$ (v/v) Antibiotic-Antimycotic solution at $37^{\circ} \mathrm{C}$ in an atmosphere of $5 \% \mathrm{CO}_{2} / 95 \%$ air. MDA-MB-231 cells were maintained in L-15 medium supplemented with 10\% FBS and $1 \%$ Antibiotic-Antimycotic solution at $37^{\circ} \mathrm{C}$ in flasks with phenolic caps.

\section{Expression of SSTR I-5 mRNA in MCF-7 and MDA-MB-23 I breast cancer cells}

SSTR1-5 and ErbB1-4 mRNA levels were measured by semi-quantitative RT-PCR in MCF-7 (ER+) and MDA-MB231 (ER $\alpha$-) breast cancer cells as previously described with some modifications $[15,68]$. Briefly, $5 \mu \mathrm{g}$ of DNA-free 
RNA was reverse transcribed and the resulting cDNA samples were amplified by PCR using the following primers:

hSSTR1 forward 5'-TGGTGGGCTTCGTGTTGT-3'

reverse 5'-GATGACCGACAGCTGACTCA-3'

hSSTR2 forward 5'-ATCTGGGGCTTGGTACACAG-3'

reverse 5'-GAAGACAGCCACCACGAT-3'

hSSTR3 forward 5'-TCATCTGCCTCTGCTACCTG-3'

reverse 5'-TTGAAGCGGTAGGAGAGGAA-3'

hSSTR4 forward 5'-CGCTCGGAGAAGAAAATCAC-3'

reverse 5'-CCCACCTTTGCTCTTGAGAG-3'

hSSTR5 forward 5'-CTCTCTCTGGACCTTGTGCC-3'

reverse 5'-ACGAGCAAACAGGTACGCTT-3'

hErbB1 forward 5'-AGTCGCCCAAAGTTCCGTGAGT-3'

reverse 5'-TGGGAGGAAGGTGTCGTCTATG-3'

hErbB2 forward 5'-AАCTCACCTACCTGCCCACCAA-3'

reverse 5'-GTGGTATTGTTCAGCGGGTCTC-3'

hErbB3 forward 5'-CAGGTCTACGATGGGAAGTTTG-3'

reverse 5'-CTCACGATGTCCCTCCAGTCAA-3'

hErbB4 forward 5'-ACCCTTCAGCACCCAGACTACC-3'

reverse 5'-GACCACCAGAGAAAGAGAGGGG-3'

$\beta$-actin forward 5'-ATCATGAAGTGTGACGTGGAC-3'

reverse 5'-AACCGACTGCTGTCACCTTCA-3'

The PCR products were separated by electrophoresis on $1.5 \%$ agarose gels stained with ethidium bromide, visualized under UV illumination and photographed using an Alpha Innotech FluorChem 8800 (Alpha Innotech Co., San Leandro, CA).

\section{Western blot analysis}

Crude membrane extracts from MCF-7 and MDA-MB-231 cells were prepared using a glass homogenizer in $20 \mathrm{mM}$ Tris- $\mathrm{HCl}, \mathrm{pH} 7.5$ (1:300 protease inhibitor cocktail) as previously described [69]. Membrane protein $(25 \mu \mathrm{g})$ was solubilized in Laemmli sample buffer containing 62.5
$\mathrm{mM}$ Tris-HCl (pH 6.8), 25\% glycerol, 2\% SDS, 0.01\% bromophenol blue and 5\% $\beta$-mercaptoethanol. Samples were placed in boiling water for $5 \mathrm{~min}$ and fractionated by electrophoresis on a $10 \%$ SDS-polyacrylamide gel as described by Laemmli [70]. The fractionated proteins were transferred by electrophoresis to a $0.2 \mu \mathrm{m}$ nitrocellulose membrane (Trans-Blot Transfer Medium, Bio-Rad) in transfer buffer consisting of $0.025 \mathrm{M}$ Tris, $0.19 \mathrm{M}$ glycine and $15 \%$ methanol. Western Blot analysis was performed as previously described with slight modifications [71]. Briefly, membranes were blotted with anti-SSTRs polyclonal (dilution 1:400) and anti-ErbB polyclonal (dilution 1:600-1500) antibodies. Blocking of membranes, incubation with primary and secondary antibodies and detection by chemiluminescence were performed with the WesternBreeze $^{\circledast}$ kit according to manufacturer's instructions. Molecular weights were estimated using the MagicMark XP Western Protein Standard (Invitrogen). Images were captured using an Alpha Innotech FluorChem 8800 gel box imager.

\section{Immunocytochemistry}

MCF-7 and MDA-MB-231 cells were plated on glass coverslips in 24-well plates and processed for indirect immunofluorescence for colocalization as previously described with slight modifications [16]. Cells were washed once in PBS and fixed with 4\% paraformaldehyde on ice for 20 minutes. After two subsequent washes in PBS, cells were incubated with 5\% NGS (diluted in PBS) for 1.5 hours followed by incubation with SSTR (1:500) and ErbB (1:150) antibodies in $1 \%$ NGS (in PBS) for $48 \mathrm{~h}$ at $4{ }^{\circ} \mathrm{C}$. Cells were then washed twice in PBS followed by incubation with Cy3-conjugated goat anti-mouse (1:500) or Cy3-conjugated donkey anti-sheep (1:500) and FITC-conjugated goat anti-rabbit (1:100) secondary antibodies for 3 hours. After two subsequent washes in PBS, cells were mounted and viewed under a Leica DMLB microscope attached to a CoolSnap CCD camera. Adobe Photoshop was used, in a consistent manner, to create the overlays and to adjust the contrast and brightness of all images.

\section{Quantitative analysis}

Counting of SSTR-, ErbB- and SSTR+ErbB-positive cells was performed directly at high magnification $(40 \times)$ under a Leica DMLB microscope. At least 8 horizontal and 8 vertical fields per coverslip were randomly selected for each receptor combination. Total number of cells positive for either one or both receptors was considered as $100 \%$ and percent colocalization was calculated accordingly. Total number of cells counted per coverlip ranged from 205 to 877.

\section{Abbreviations}

SSTR, somatostatin receptor; ErbB, epidermal growth factor receptor; ER, estrogen receptor; SST, somatostatin; 
GPCR, G protein-coupled receptor; RTK, receptor tyrosine kinase; MAPK, mitogen activated protein kinase; FBS, fetal bovine serum; NGS, normal goat serum

\section{Authors' contributions}

HLW carried out all experiments, participated in the design of the study, performed the statistical analysis and helped to draft the manuscript. UK conceived the study, participated in its design and helped to draft the manuscript.

\section{Acknowledgements}

This work was funded Canadian Institute of Health Research (CIHR) grants MOP-104I I, MOP-74465 and MOP-6I96 (UK). We thank Archana

Venugopalan for technical support and Maria Correia for secretarial help.

\section{References}

I. Patel YC: Somatostatin and its receptor family. Frontiers in Neuroendocrinology 1999, 20:157-198.

2. Patel YC, Srikant CB: Somatostatin receptors. Trends Endocrinol Metab 1997, 8:398-405.

3. Patel YC: Basic aspects of somatostatin receptors. In Advances in Molecular and Cellular Endocrinology Edited by: LeRoith D. Greenwich, CT , JAI Press; 1998.

4. Ciocca DR, Puy LA, Fasoli LC, Tello O, Aznar JC, Gago FE, Papa SI, Sonego R: Corticotropin releasing hormone, leutinizing hormone releasing hormone, growth hormone releasing hormone, and somatostatin-like immunoreactivities in biopsies from breast cancer patients. Breast Cancer Res Treat 1990, 15:175-184.

5. Nelson J, Cremin M, Murphy RF: Synthesis of somatostatin by breast cancer cells and their inhibition by exogenous somatostatin and sandostatin. Br J Cancer 1989, 59:739-742.

6. Sharma K, Srikant CB: Induction of wild-type $\mathbf{p 5 3}$ Bax and acidic endonuclease during somatostatin signaled apoptosis in MCF-7 human breast cancer cells. Int J Cancer 1998, 76:259-266.

7. Papotti M, Kumar U, Volante M, Pecchioni C, Patel YC: Immunohistochemical detection of somatostatin receptor types I-5 in medullary carcinoma of the thyroid. Clin Endocrinol (Oxf) 200I, 54:64I-649.

8. Panetta R, Patel YC: Expression of mRNA for all five human somatostatin receptors (hSSTR I-5) in pituitary tumors. Life Sci 1995, 56:333-342.

9. Reubi JC, Schaer JC, Waser B, Mengod G: Expression and localization of somatostatin receptor SSTR I, SSTR2 and SSTR3 mRNAs in primary human tumors using in situ hybridization. Cancer Res 1994, 54:3455-3459.

10. Prevost G, Hosford D, Thomas F: Receptors for somatostatin and somatostatin analogues in human breast tumors. Ann $N$ Y Acad Sci 1994, 733:147-154.

II. Prevost G, Lanson M, Thomas F, Veber N, Gonzalez W, Beaupain R, Starzec A, Bogden A: Molecular heterogeneity of somatostatin analogue BIM-230 I 4C receptors in human breast carcinoma cells using the chemical cross-linking assay. Cancer Res 1992 52:843-850.

12. Foekens JA, van Putten WL, Portengen H, Rodenburg C], Reubi IC, Berns PM, Henzen-Logmans SC, van der Burg ME, Alexieva-Figusch J, Klijn JG: Prognostic value of pS2 protein and receptors for epidermal growth factor (EGF-R), insulin-like growth factorI (IGF-I-R) and somatostatin (SS-R) in patients with breast and ovarian cancer. I Steroid Biochem Mol Biol 1990, 37:8I5-82I.

13. Fekete M, Wittliff A, Schally AV: Characteristics and distribution of receptors for [D-Trp6]-luteinizing-releasing hormone, somatostatin, epidermal growth factor, and sex steroids in $\mathbf{5 0 0}$ biopsy samples of human breast cancer. J Clin Lab Anal 1989, 3:137-147.

14. Foekens JA, Portengen $\mathrm{H}$, van Putten WLJ, Trapman A, Reubi JC, Alexieva-Figusch J, Klijn JGM: Prognostic value of receptors for insulin-like growth factor I, somatostatin, and epidermal growth factor in human breast cancer. Cancer Res 1989. 49:7002-7009.
15. Kumar U, Grigorakis SI, Watt HL, Sasi R, Snell L, Watson P, Chaudhari S: Somatostatin receptors in primary human breast cancer: quantitative analysis of mRNA for subtypes I-5 and correlation with receptor protein expression and tumor pathology. Breast Cancer Res Treat 2005, 92: I75-186.

16. Rivera JA, Alturaihi H, Kumar U: Differential regulation of somatostatin receptors $I$ and 2 mRNA and protein expression by tamoxifen and estradiol in breast cancer cells. Journal of Carcinogenesis 2005, 4(I): 10-19.

17. Wiseman SM, Makretsov N, Nielsen TO, Gilks B, Yorida E, Cheang $M$, Turbin D, Gelmon K, Huntsman DG: Coexpression of the type I growth factor receptor family members HER-I, HER-2, HER-3 has a synergistic negative prognostic effect on breast carcinoma survival. Cancer 2005, 103:1770-1777.

18. Abd El-Rehim DM, Pinder SE, Paish CE, Bell JA, Rampaul RS, Blamey RW, Robertson JFR, Nicholson RI, Ellis IO: Expression and coexpression of the members of the epidermal growth factor receptor (EGFR) family in invasive breast carcinoma. $\mathrm{Br}$ Cancer 2004, 91:1532-1542

19. Kilinç N, Yaldiz M: P53, c-erbB-2 expression and steroid hormone receptors in breast carcinoma: correlations with histopathological parameters. Eur J Gynaecol Oncol 2004, 25:606-610.

20. Esteva FJ, Hortobagyi GN, Sahin AA, Smith TL, Chin DM, Liang SY, Pusztai L, Buzdar AU, Bacus SS: Expression of erbB/Her receptors, Heregulin and p38 in primary breast cancer using quantitative immunohistochemistry. Pathology Oncology Research 200I, 7:17I-I77.

21. Suo Z, Bjaamer A, Ottestad L, Nesland JM: Expression of EGFR family and steroid receptor hormone receptors in ductal carcinoma in situ of the breast. Ultrastructural Pathology 200I, 25:349-356.

22. deFazio A, Chiew YE, Sini RL, Janes PW, Sutherland RL: Expression of c-erbB receptors, heregulin, oestrogen receptor in human breast cell lines. Int J Cancer 2000, 87:487-498.

23. Sweeney C, Carraway KL: Ligand discrimination by ErbB receptors: differential signaling through differential phosphorylation site usage. Oncogene 2000, 19:5568-5573.

24. Tzahar E, Pinkas-Kramarski R, Moyer JD, Klapper LN, Alroy I, Levkowitz G, Shelly M, Henis S, Eisenstein M, Ratzkin BJ, Sela M, Andrews GC, Yarden Y: Bivalence of EGF-like ligands drives the ErbB signaling network. EMBO J 1997, 16(16):4938-4950.

25. Witton CJ, Reeves JR, Going JJ, Cooke TG, Bartlett JMS: Expression of the HERI-4 family of receptor tyrosine kinases in breast cancer. Journal of Pathology 2003, 200:290-297.

26. Spaventi R, Kamenjicki E, Pecina N, Grazio S, Grazio S, Pavelic J, Kusic B, Cvrtila D, Danilovic Z, Spaventi S, Pavelic K, Gluckman J, Pavelic ZP: Immunohistochemical detection of TGF-a, EGF-R, cerbB-2, c-H-ras, c-myc, estrogen and progesterone in benign and malignant human breast lesions: a concommitant expression? In vivo 1994, 8:183-190.

27. Reubi JC, Torhorst J: The relationship between somatostatin, epidermal growth factor, and steroid hormone receptors in breast cancer. Cancer 1989, 64(6): $1254-1260$

28. Naidu R, Yadav M, Nair S, Kutty MK: Expression of c-erbB3 protein in primary breast carcinomas. $\mathrm{Br} J$ Cancer 1998, 78: $1385-1390$.

29. Travis A, Pinder SE, Robertson HFR, Bell JA, Wencyk P, Gullick WJ, Nicholson RI, Poller DN, Blamey RW, Elston CW, Ellis IO: C-erbB3 in human breast carcinoma: expression and relation to prognosis and established prognostic indicators. $\mathrm{Br} J$ Cancer 1996, 74(2):229-233.

30. Srinivasan R, Gillett CE, Barnes DM, Gullick WJ: Nuclear expression of the c-erbB-4/HER-4 growth factor receptor in invasive breast cancers. Cancer Research 2000, 60:|483-| 487.

31. Tang CK, Concepcion XZ, Milan M, Gong X, Montgomery E, Lippman ME: Ribozyme-mediated down-regulation of ErbB-4 in estrogen receptor-positive breast cancer cells inhibits proliferation both in vitro and in vivo. Cancer Research 1999 , 59:5315-5322.

32. Srikant CB: Cell cycle dependent induction of apoptosis by somatostatin analog SMS 20 I-995 in AtT-20 mouse pituitary cells. Biochem Biophys Res Commun 1995, 209(2):400-406.

33. Pagliacci MC, Tognellini R, Grignani F, Nicoletti I: Inhibition of human breast cancer cell (MCF-7) growth in vitro by the somatostatin analog SMS 20I-995: effects on cell cycle 
parameters and apoptotic cell death. Endocrinology |99|, 1 29(5):2555-2562.

34. Szende B, Srkalovic G, Schally AV, Lapis K, Groot K: Inhibitory effects of analogs of luteinizing hormone-releasing hormone and somatostatin on pancreatic cancers in hamsters. Events that accompany tumor regression. Cancer 1990, 65(10):2279-2290.

35. Carpenter G: EGF receptor transactivation mediated by the proteolytic production of EGF-like agonists. SCi STKE 2000, 2000(15):PEI.

36. Daub H, Weiss FU, Wallash C, Ullrich A: Role of transactivation of the EGF receptor in signalling by G-protein coupled receptors. Nature 1996, 379:557-560.

37. Fergusson SSG: Receptor tyrosine kinase transactivation: finetuning synaptic transmission. Trends in Neurosciences 2003, 26:119-122.

38. Pierce KL, Premont RT, Lefkowitz RJ: Seven-transmembrane receptors. Nat Rev Mol Cell Biol 2002, 3:639-650.

39. Wetzker R, Böhmer FD: Transactivation joins multiple tracks to the ERK/MAPK cascade. nat rev mol cell biol 2003, 4:65I-657.

40. Prenzel N, Zwick E, Daub H, Leserer M, Abraham R, Wallash C, Ullrich $A$ : EGF receptor transactivation by $G$-protein-coupled receptors requires metalloproteinase cleavage of proHBEGF. Nature 1999, 402:884-888.

4I. Luttrell LM, Daaka Y, Lefkowitz RJ: Regulation of tyrosine kinase cascades by G-protein-coupled receptors. Current opinion in cell biology 1999, I I: 177-183.

42. Schäfer B, Gshwing A, Ullrich A: Multiple G-protein-coupled receptor signals converge on the epidermal growth factor receptor to promote migration and invasion. Oncogene 2004, 23:991-999.

43. Bièche I, Onody P, Tozlu S, Driouch K, Vidaud M, Lidereau R: Prognostic value of erbB family mRNA expression in breast carcinomas. Int / Cancer 2003, 106:758-765.

44. Walker RA, Dearing SJ: Expression of epidermal growth factor receptor mRNA and protein in primary breast carcinomas. Breast Cancer Res Treat 1999, 53:167-176.

45. Lacroix M, Leclercq G: Relevance of breast cancer cell lines as models for breast tumors: an update. Breast Cancer Res Treat 2004, 83:249-289.

46. Kumar U, Laird D, Srikant CB, Escher E, Patel YC: Expression of the five somatostatin receptor (SSTRI-5) subtypes in rat pituitary somatotrophes: quantitative analysis by doublelabel immunofluorescence confocal microscopy. Endocrinology 1997, 1 38( I 0):4473-4476.

47. Patel YC, Greenwood MT, Warszynska A, Panetta R, Srikant CB: All five cloned human somatostatin receptors (hSSTRI-5) are functionally coupled to adenylyl cyclase. Biochem Biophys Res Commun 1994, 198(2):605-6I2.

48. Grant M, Patel R, Kumar U: The role of subtype-specific ligand binding and the C-tail domain in dimer formation of human somatostatin receptors. J Biol Chem 2004, 279(37):38636-38643.

49. Rocheville M, Lange DC, Kumar U, Sasi R, Patel RC, Patel YC: Subtypes of the somatostatin receptor assemble as functional homo- and heterodimers. J Biol Chem 2000, 275(I I):7862-7869.

50. Ciocca DR, Elledge R: Molecular markers for predicting response to tamoxifen in breast cancer patients. Endocrine 2000, I 3(I): I- 10 .

5I. Olayioye MA, Neve RM, Lane H, Hynes NE: The ErbB signaling network: receptor heterodimerization in development and cancer. The EMBO Journal 2000, 19:3159-3167.

52. Mueller H, Loop P, Liu R, Wosikowski K, Kueng W, Eppenberger U: Differential signal transduction of epidermal-growth-factor receptors in hormone-dependent and hormone-independent human breast cancer cells. Eur I Biochem 1994 22I(2):63I-637.

53. deFazio A, Chiew YE, Donoghue C, Lee CS, Sutherland RL: Effect of sodium butyrate on estrogen receptor and epidermal growth factor receptor gene expression in human breast cancer cell lines. J Biol Chem 1992, 267(25): I8008-I80I2

54. Godden J, Leake R, Kerr DJ: The response of breast cancer cells to steroid and peptide growth factors. Anticancer Research 1992 I 2(5): 1683-| 688.

55. Weber C, Merriam L, Koschitzky T, Karp F, Benson M, Forde K, Logerfo P: Inhibition of growth of human breast carcinomas in vivo by somatostatin analog SMS 201-995: treatment of nude mouse xenografts. Surgery 1989, 106(2):416-422.

56. Buscail L, Vernejoul F, Faure P, Torrisani J, Susini C: Regulation of cell proliferation by somatostatin. Ann Endocrinol (Paris) 2002, 63(2 Pt 3):2S|3-2SI8.

57. Cattaneo MG, Taylor JE, Culler MD, Nisoli E, Vicentini LM: Selective stimulation of somatostatin receptor subtypes: differential effects on Ras/MAP kinase pathway and cell proliferation in human neuroblastoma cells. FEBS Letters 2000, 48 I:27I-276.

58. Florio T, Thellung S, Arena S, Corsaro A, Bajetto A, Schettini G, Stork PJ: Somatostatin receptor I (SSTRI)-mediated inhibition of cell proliferation correlates with the activation of the MAP kinase cascade: role of the phosphotyrosine phosphatatse SHP-2. J Physiol Paris 2000, 94(3-4):239-250.

59. Keshamouni VG, Mattingly RR, Reddy KB: Mechanism of I7- $\beta$ estradiol-induced erk $1 / 2$ activation in breast cancer cells. J Biol Chem 2002, 277:22558-22565.

60. Watters J], Campbell JS, Cunningham MJ, Krebs EG, Dorsa DM: Rapid membrane effects of steroids in neuroblastoma cells: effects of estrogen on mitogen activated protein kinase signalling cascade and c-fos immediate early gene transcription. Endocrinology 1997, 138(9):4030-4033.

61. Migliaccio A Di Domenico M, Castoria G, de Falco A, Bontempo P, Nola E, Auricchio F: Tyrosine kinase/p2 I ras/MAP-kinase pathway activation by estradiol-receptor complex in MCF-7 cells. EMBO ] 1996, I 5(6): 1292-1300.

62. Duan L, Miura Y, Dimri M, Majumder B, Dodge IL, Reddi AL, Ghosh A, Fernandes N, Zhou P, Mullane-Robinson K, Rao N, Donoghue $S$, Rogers RA, Bowtell D, Naramura M, Gu H, Band V, Band H: Cblmediated ubiquitinylaiton is required for lysosomal sorting of epidermal growth factor receptor but is dispensible for endocytosis. J Biol Chem 2003, 278:28950-28960.

63. Hipkin RW, Friedman J, Clark RB, Eppler CM, Schonbrunn A: Agonist-induced desensitization, internalization, and phosphorylation of the sst2A somatostatin receptor. J Biol Chem 1997, 272(2I): 13869-13876.

64. Roth A, Kreienkamp HJ, Meyerhof W, Richter D: Phosphorylation of four amino acid residues in the carboxyl terminus of the rat somatostatin receptor subtype 3 is crucial for its desensitization and internalization. I Biol Chem 1997 272(38):23769-23774.

65. Hukovic N, Panetta R, Kumar U, Patel YC: Agonist-dependent regulation of cloned human somatostatin receptor types I-5 (hSSTRI-5): subtype selective internalization or upregulation. Endocrinology 1996, 137(9):4046-4049.

66. Kumar $U$ : Expression of somatostatin receptor subtypes (SSTRI-5) in alzheimer's disease brain: an immunohistochemical analysis. Neuroscience 2005, 134:525-538.

67. Kumar U, Sasi R, Suresh S, Patel A, Thangaraju M, Metrakos P, Patel SC, Patel YC: Subtype-selective expression of the five somatostatin receptors (hSSTRI-5) in human pancreatic islet cells. Diabetes 1999, 48:77-85.

68. Khare S, Kumar U, Sasi R, Puebla L, Calderon L, Lemstrom K, Hayry $P$, Patel YC: Differential regulation of somatostatin receptor types I-5 in rat aorta after angioplasty. Faseb J 1999, 1 3:387-394.

69. Ramirez JL, Watt HL, Rocheville M, Kumar U: Agonist-induced upregulation of human somatostatin receptor type $I$ is regulated by $\beta$-arrestin-I and requires an essential serine residue in the receptor C-tail. Biochimica et Biophysica Acta 2005, 1669:182-192.

70. Laemmli UK: Cleavage of structural proteins during the assembly of the head of bacteriophage T4. Nature 1970, 227(5259):680-685.

7I. Ramirez JL, Grant M, Norman M, Wang XP, Moldovan S, de Mayo FJ, Brunicardi C, Kumar U: Deficiency of somatostatin (SST) receptor type 5 (SSTR5) is associated with sexually dimorphic changes in the expression of SST and SST receptors in brain and pancreas. Molecular and Cellular Endocrinology 2004, 221:105-119. 